\title{
A Tribute to the Remaining Makyong Performers of Yala, South Thailand Sanjungan Untuk Para Penggiat Makyong di Yala, Selatan Thailand
}

\author{
Tan Sooi Beng and A.S. Hardy Shafii \\ Universiti Sains Malaysia \\ Correspondence: $\underline{\text { sbtan2@gmail.com }}$
}

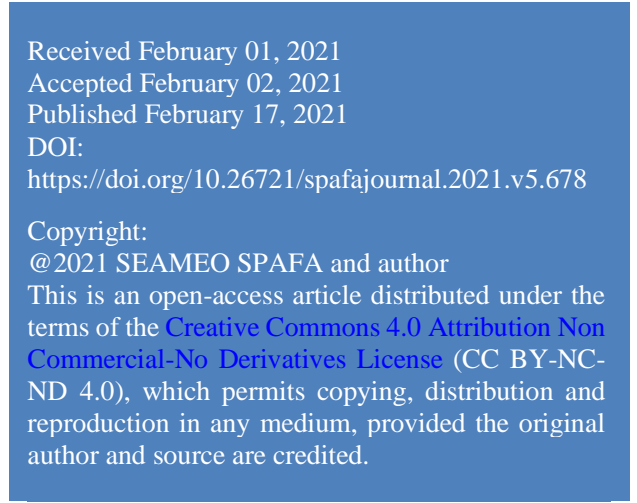

\begin{abstract}
Makyong is a form of Malay dance-theatre that combines dance, music, drama and comedy. It is said to have originated in the kingdom of Patani and later spread to Kelantan, Perlis, northern Sumatra and the Riau Islands. In the past, Makyong was performed to give thanks for a good harvest and for ritual healing. While there were more than ten active groups in the twentieth century, there is no permanent group left in South Thailand today. This essay honours the remaining performers who still come together to perform Makyong when there is an invitation. Based on oral interviews, we document the lives of the veteran performers, particularly the female actresses who played the leading roles. Through observations of their performances, we show how the Makyong performers in south Thailand have adapted some elements of Thai theatre.
\end{abstract}

Makyong merupakan sebuah bentuk teater tradisional Melayu yang menggabungkan tarian, muzik, drama dan komedi. Persembahan ini dipercayai berasal dari kesultanan Patani dan kemudian berkembang ke negeri Kelantan, Perlis, Sumatera Utara dan kepulauan Riau. Pada masa dahulu, Makyong dipersembahkan sebagai tanda kesyukuran di atas penuaian padi yang baik serta untuk ritual perubatan. Terdapat lebih dari sepuluh kumpulan Makyong yang aktif pada abad kedua puluh, namun kini tiada lagi kumpulan tetap Makyong yang bergiat di selatan Thailand. Esei ini merupakan satu tanda sanjungan kepada para penggiat Makyong yang masih lagi tegar dan bersemangat untuk berkumpul dalam melestarikan Makyong apabila dijemput untuk menjayakan persembahan ini. Berlandaskan beberapa temubual lisan, kami mendokumentasikan kehidupan penggiat veteran Makyong, terutamanya pemain wanita yang memegang watak utama. Melalui pemerhatian terhadap beberapa persembahan tersebut, kami menceritakan bagaimana penggiat Makyong di selatan Thailand memancarkan beberapa pengaruh Thai ke dalam persembahan ini.

Keywords: Makyong, Malay theatre, female performers of South Thailand | Makyong, teater Melayu, pelakon perempuan Thai Selatan 
Dance, music, humour, prayers, offerings... that was what awaited the young and old villagers, curious children and members of the press who had gathered to watch an infrequent Makyong performance by the veteran performers of the Makyong Seri Bulan Tarian troupe at an open space opposite the museum at Raman, Yala, South Thailand. The drummers and gong player were seated on floor mats that marked the performance space. They were following the lead of the rebab, a three-stringed spiked fiddle; this instrument is essential in any Makyong performance as it connects the performers to the spiritual realm.

The audience crowded around the four sides of the performance space as the the buka panggung (opening the theatre) ritual took place (Figure 1). Prayers were chanted by the spiritual leader. The instruments were blessed with incense, candles were placed on the drums, while pop rice (bertih) was scattered at the four corners of the stage area to ensure that no mishap would occur during the performance. The opening songs (lagu Bertabuh) were then played to announce the beginning of the show.

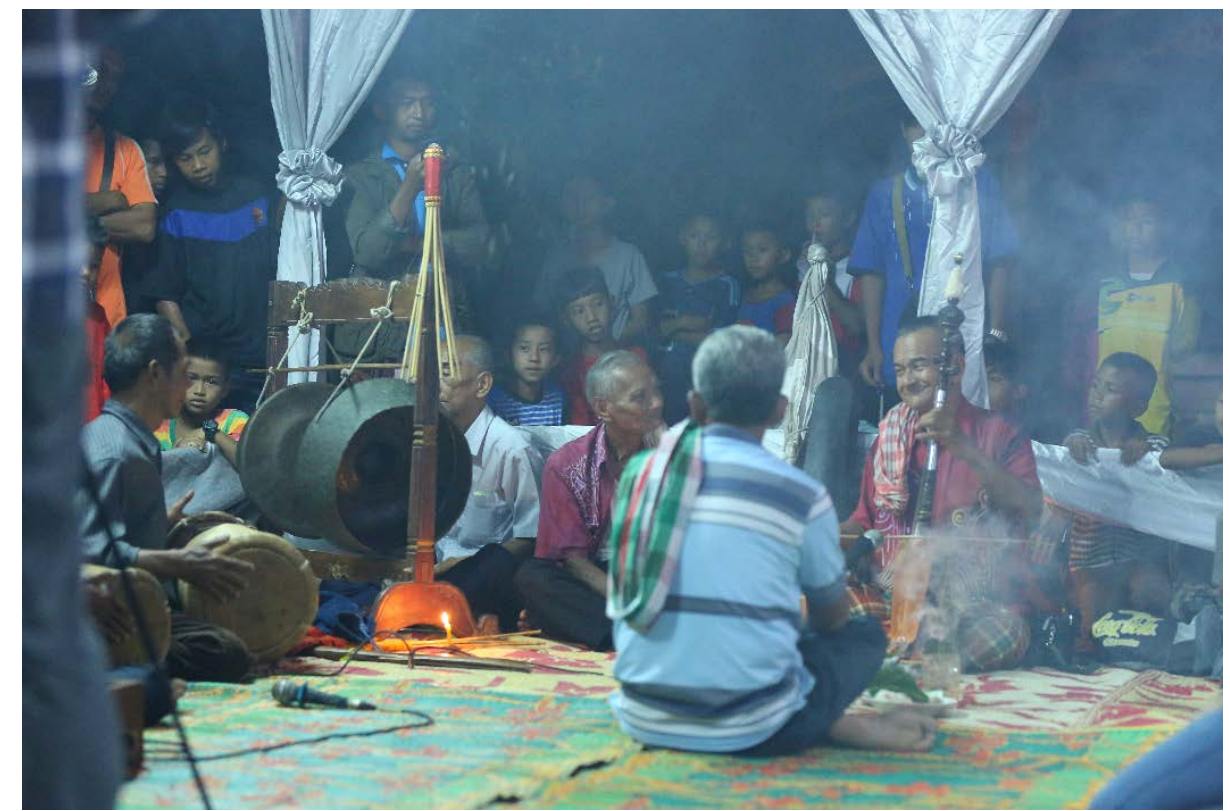

Fig. 1 Buka panggung (opening the theatre) ceremony, blessing the rebab, drums and gongs. Source: A. S. Hardy Shafii.

All at once, an air of excitement prevailed as the predominantly female Makyong performers entered the stage area and silat (Malay art of self defence) was enacted to the accompaniment of additional instruments such as the serunai (double-reeded shawm), kesi (cymbals) and canang (inverted gongs) that are also used in wayang kulit (shadow play). The 77-year-old Mek Munoh, the female Pak Yong (King character) in the performance started singing the lagu Gerak Bangun (literally Waking Up Movement song, Figure 2). This song is also known as lagu Menghadap Rebab (Salutaton to the Rebab) in Kelantan. Following tradition, Mek Munoh led the female actresses in song and dance as they faced east moving in front of the rebab player. The women dancers portrayed imageries of animals, birds and plants through their hand, finger and body movements. One could not help feeling that the stage was some kind of enchanted place filled with the magical wonder of nature. 


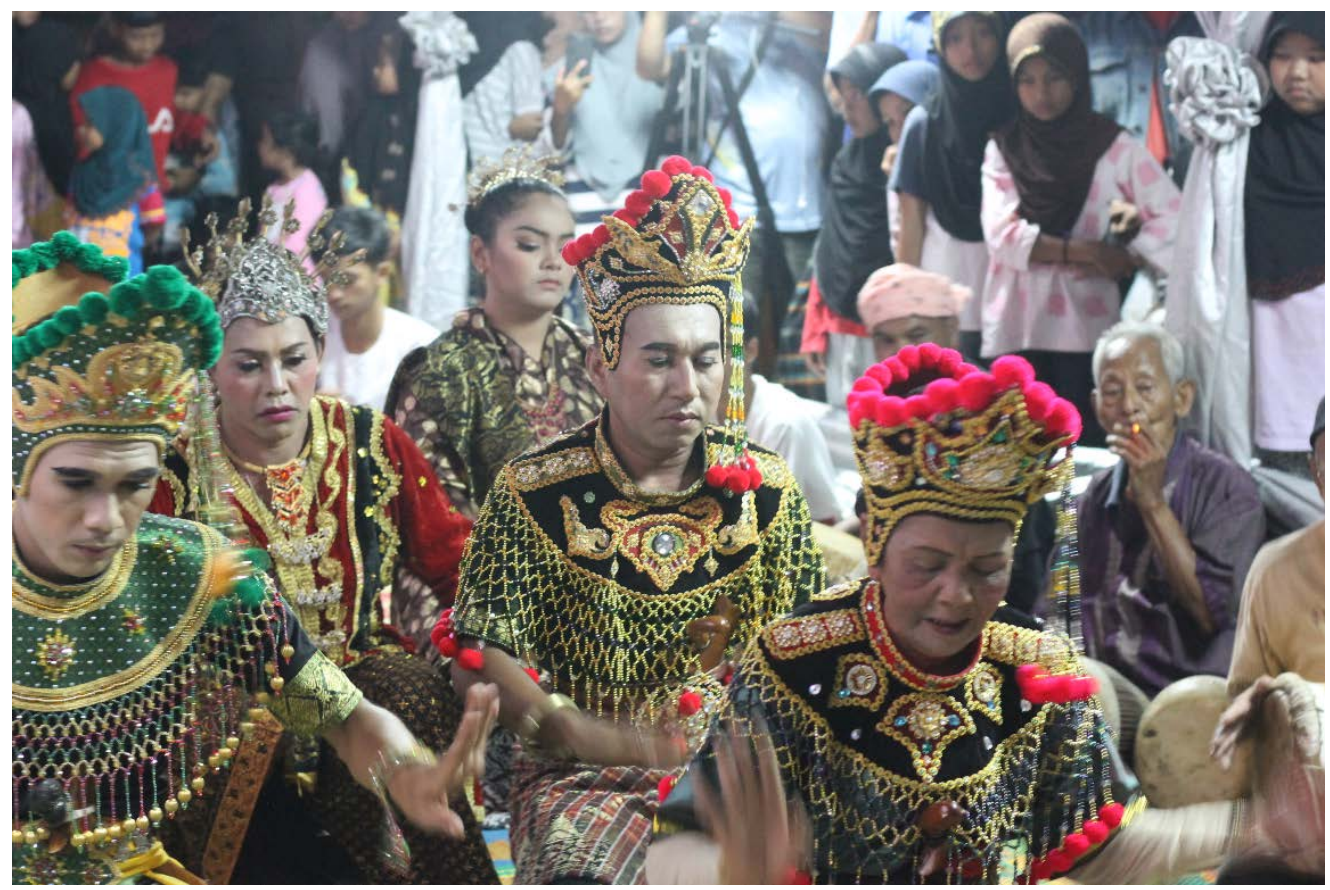

Fig. 2 Lagu Gerak Bangun, Mek Munoh as female Pak Yong (front right, with red decorations) and Saman Dosormi as Pak Yong Muda (behind Mek Munoh with red decorations). Source: A. S. Hardy Shafii.

The lagu Gerak Bangun signaled the beginning of a set of song-dance sequences that introduced the main characters, which were performed at all Makyong shows. The lagu Gerak Pengasuh (Movement of the Mentors Song or lagu Sedayong Pak Yong in Kelantan) announced the main lead characters such as the King and Prince who are central to any Makyong performance. The lagu Fikir (literally Thinking song), also known as lagu Sedayong Mak Yong in Kelantan, presented the female lead such as the Queen and Princess. Two other songs Pak Yong with Peran Tua and Peran Muda (old and young clowns respectively) brought out the comic characters that were the two attendants. The Pak Yong characters were dressed in traditional costume with headdress while the others wore their best going-out clothes.

There was a sudden flurry of excitement as the music became livelier and the dancers switched to the Lilit Kacang dance formation in the middle of the lagu Fikir (Figure 3); the musicians added the serunai and canang to liven up the song-dance. Some small children jumped in to play the kecerek, two percussion bamboo sticks that are commonly used in Thai Menora. The antics of the attendants played by male and female clowns, the late Alee Chehama (70 years old) and Che Som (73 years old) respectively, drew the most laughs from all present. It wasn't just the story that stirred a certain emotion in the audience as everything that took place onstage, from the dance, music and jokes, made it all the more memorable. 


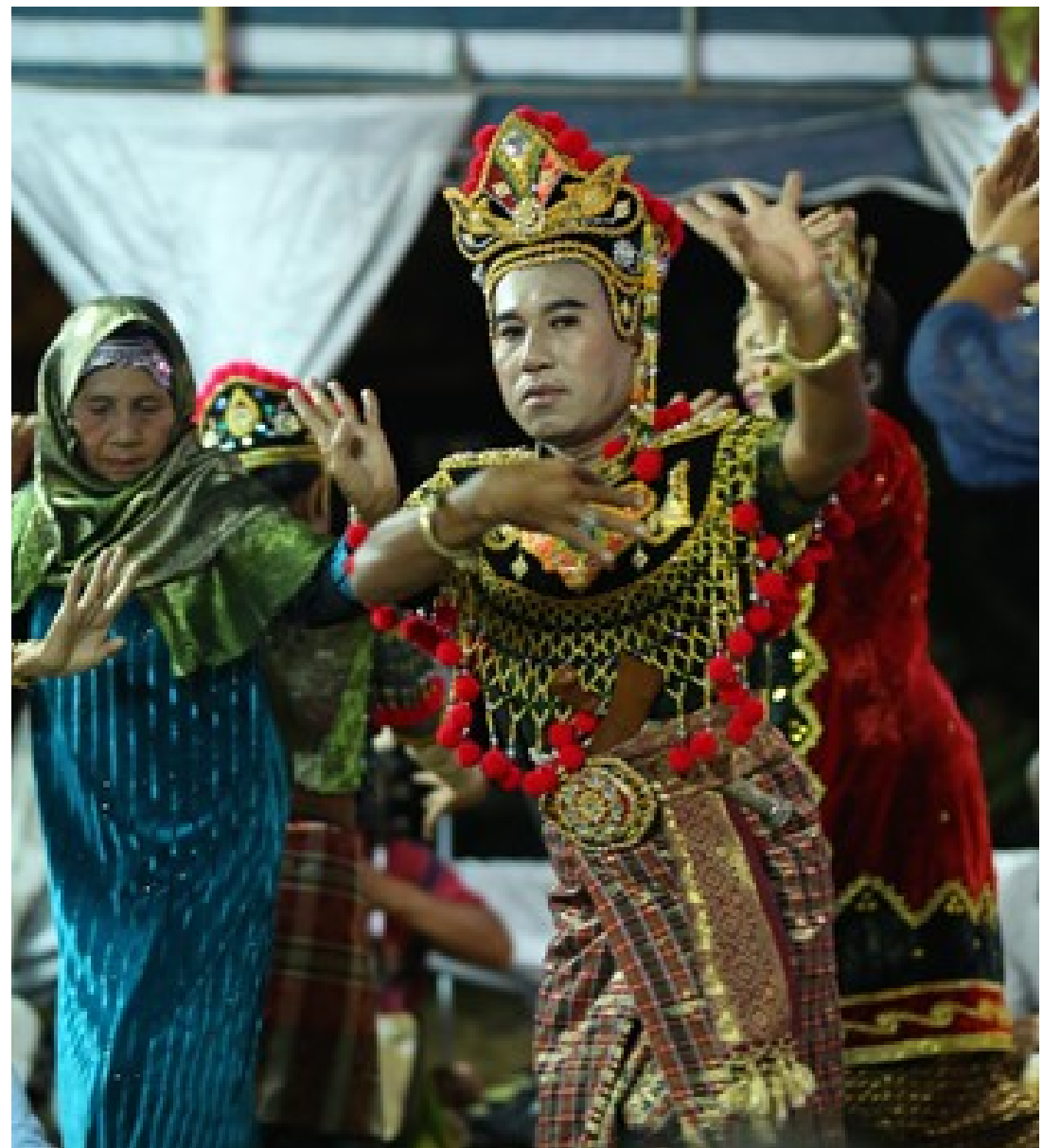

Fig. 3 Lilit Kacang dance formation with Saman Dosormi in front. Source: A. S. Hardy Shafii.

This was a Makyong performance that was sponsored by the researchers from Universiti Sains Malaysia at the Ke-Meng Folk Museum Chalermraja Cultural Centre at Raman in July 2019. Located in Southern Thailand's Yala province, this area together with neighbouring Pattani and Narathiwat, has been affected by decades of violent armed conflict between separatists and Thai authorities. Despite the potential risks and being stopped by the Thai military at roadblocks, the research team managed to document the Makyong performance and interviewed the veteran performers then.

This essay is an ode to the last Makyong performers of Yala, two of whom have passed away since our visit in 2019. Saman Dosormi, the head of Ke-Meng Folk Museum Chalermraja Cultural Centre, had called on the old performers from various parts of South Thailand to perform as there is no permanent troupe left. He said, "there are very few performances these days unless there are specific events like the Malay Day or if someone pays for a show” (personal communication 28 July, 2019, Raman). The old female Makyong performers such as Mek Munoh, Che Timoh and Mak Teh had travelled from various villages around Yala to join the performance. Ali Chehama came all the way from Narathiwat to perform the Peran Tua part. Che Amat Bunohan from Kelantan had been invited to play the rebab. 


\section{Makyong in South Thailand}

Makyong is a form of Malay dance-theatre that combines dance, music, drama and comedy. According to Makyong researcher Ghulam-Sarwar (1982), the songs and dances such as the lagu Mengadap Rebab invoke spirits connected to nature such as the Mak Hiang, the spirit of rice. In the past, Makyong was performed to celebrate a good harvest and for ritual healing. The hand movements in this opening dance represent 'earth, water, fire and wind' and the 'four elements of the human body' (Hardwick 2014: 42).

Makyong is believed to have originated in the kingdom of Patani, now a part of southern Thailand. The veteran performers say that Makyong flourished in Bukit Serkam in Patani (Hardy Shafii 2017). This comes as no surprise as the court chronicle Hikayat Patani (written in the late seventeenth century) tells us that during the regn of Raja Ijau (Green Queen), Patani was not only famous for its international trade but was a cultural centre for music, dance and theatre (Teeuw and Wyatt 1970: 257-8). Peter Floris, an English traveller who attended a dance performance at the Queen's palace in 1613 declared that he witnessed " 12 women and children who danced so well that he had not seen better in all the Indies." He also saw a "playde a commedya” (comedy play) performed by women that was "very pleasaunte to beholde" (pleasant to behold) (quoted in Amirell 2011: 312). Makyong is said to have spread to the northern Malaysian states of Kelantan, Trengganu and Kedah, parts of north Sumatera and Riau islands in Indonesia. It is still performed in Kelantan and Riau Islands, albeit with local adaptations by the respective performers today.

The 81-year-old musician Che Dae claims that "there were ten active groups in the Patani, Yala and Narathiwat areas in the past: Kumpulan Pok Leh, Kumpulan Che Penawar, Kumpulan Che Muda, Kumpulan Che Ning, Kumpulan Kak Wei, Kumpulan Ku Som Ku Wok, Kumpulan Mat Yamin, Kumpulan Jenab, Kumpulan Jeringai, Kumpulan Kak Nan” (personal communication Che Dae, 30 July 2019, Yala). Mek Munoh added that in those days, many troupes operated in Mayo, Yala and Bukit Serkam, Patani (personal communication, 28-30 July, 2019 Yala). Even though the actors and actresses were poor and had to earn their living by tapping rubber or farming, Makyong was their passion and they enjoyed playing at weddings, festivals and for ritual healing in the past century. Nevertheless, no fixed groups survive today. Performers who are still alive are gathered by individuals such as Kak Wei, Che Jenab and Saman Dosormi whenever there is an occasion.

In many ways, the Makyong performance that we saw in Yala resembled those in Kelantan. However, some elements that are particular to southern Thailand have been included such as the performance of the silat dance and music as the Makyong performers enter the stage area. While the dance-songs in the opening sequences are shorter than those in Kelantan, the lagu Fikir or Sedayung Mak Yong section tends to be stretched out with the addition of the Lilit Kacang and as the women performers take turns to sing.

Additionally, the Makyong in Yala has been influenced by the Menora dance-theatre. The buka panggung ceremony is similar to the opening ceremony of the Menora while movements in the dance formation resemble those of the Menora dance. Other Menora elements include the use of percussion sticks (kecerek) in the livelier song-dances and the high and pointed mahkota (crown) of Pak Yong resembling the crown of the Menora dancer. Alee Chehama added that "stories such as Raja Muda Puteri Bongsu have been adapted from the repertoire of Menora" (see Hardy Shafii and Johan Othman 2020).

While the practice of women playing the Pak Yong role emerged in the early twentieth century in Kelantan as Makyong was brought into the court of Kelantan by Tengku Temenggong Ghaffar 
(Yousof 1982), female performers have been performing the main Makyong roles in Yala including that of the Peran before that. This is not surprising since women have made significant contributions to society for centuries in Patani. The seven Queens who ruled Patani in the seventeenth and eighteenth centuries are cases in point (Teeuw and Wyatt 1970). Besides the Pak Yong, Mak Yong and female attendant roles, women also take on the Peran Muda (young male attendant or comedian) parts in Yala; a role that women in Kelantan and Riau do not play. The female and male Peran are no mere clowns but they are known to be wise and they make social commentaries. "But, women do not take on the Peran Tua parts as the role is often connected with ritual healing," declared Che Som, the well-known female Peran Muda in Yala (personal communication, 28 July, 2019, Raman).

\section{The Remaining Makyong Prima Donnas, Comic Characters and Musicians in Yala}

Since our last visit to Yala in 2019, two of the old-time performers have passed away. We dedicate the rest of this essay to them and the few surviving performers in Yala.

Born in Yala on 1 January 1949, Che Som (Jehsong Samae in Thai) was the daughter of Makyong performers named Che Muda and Mek Yeh. "I started performing Makyong at the age of 12. That was when I married a rebab player named Che Din who was seven years my senior. One of our three sons, Adum, currently plays the Peran in Menora,” she declared.

When asked why she chose to be a Peran Muda, Che Som smiled saying that the "Pak Yong or Raja role did not suit my character and spirit (jiwa). I tried but I was more inclined to create laughter whenever I acted or spoke. This did not correspond with the Raja's character who was supposed to be serious and brave.” Furthermore, Che Som's aunt used to say to her, "you do not have a captivating face and your skin colour is too dark! The Pak Yong character needs to be good looking!”

Che Som recalled that she started learning the Peran Muda role by observing the senior comic characters in her father's troupe. Women were not allowed to play the Peran Tua role as they could not conduct rituals that the Peran Tua was called to perform during shows for ritual healing. In time to come, Che Som became acknowledged as a female Peran Muda and was given the nickname Pak Chu Pek. She grinned revealing "this name was funny to many as it referred to an adult male (pak su) with female sex organs (pepek)." "Everyone laughed whenever Pak Yong asked Peran Tua for the name of his assistant," she disclosed. Che Som added that she used to thrill the audience with rib-tickling performances and hilarious facial expressions. "I looked funny as I had half a moustache above the right side of my mouth, painted my face white with bedak (powder) and wore a hat, Hawaiian shirt and baggy clothes," she chuckled (Figure 4). 


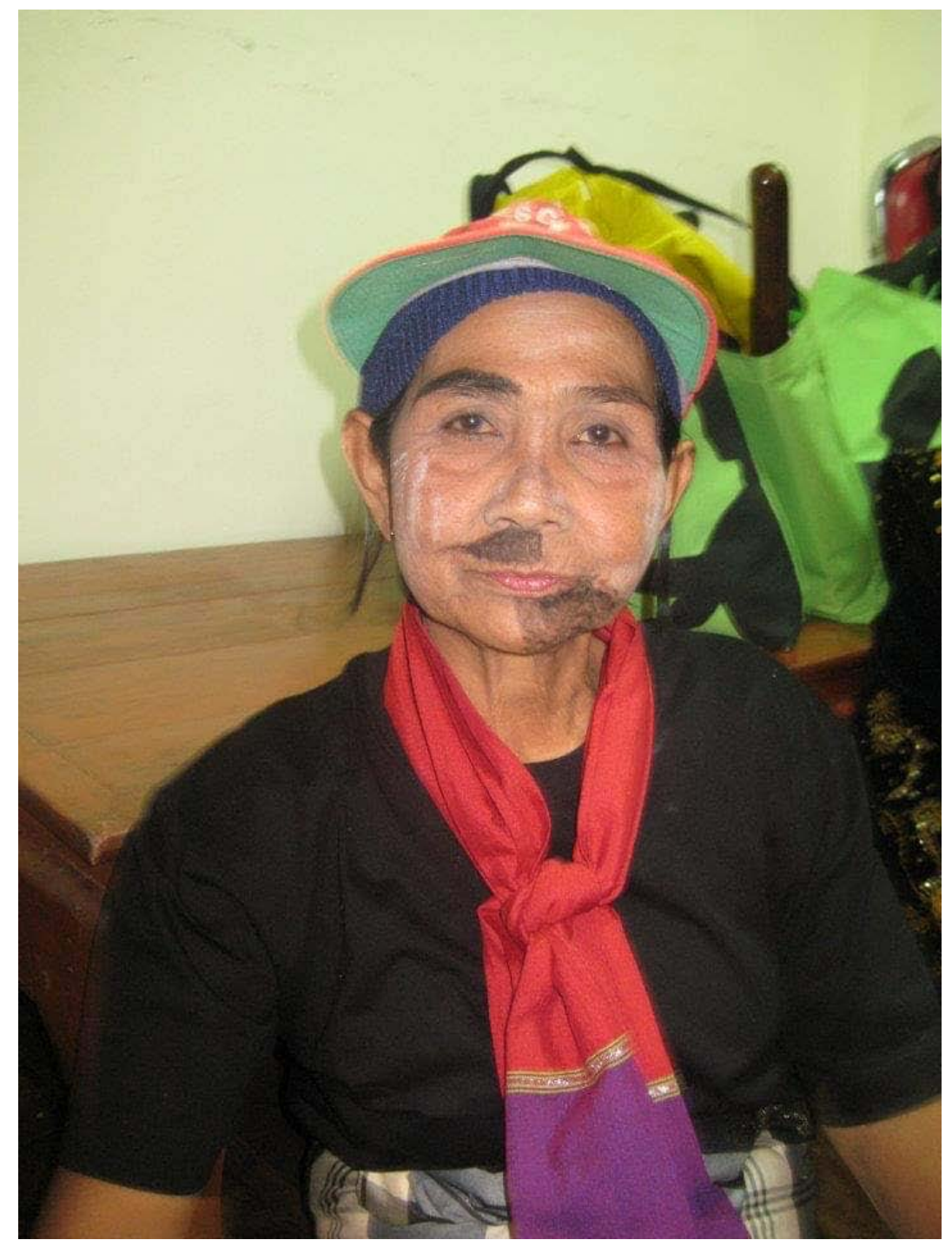

Fig. 4 Che Som as Peran Muda with half a moustache, powdered face and hat. Source: A. S. Hardy Shafii.

Che Som remarked that the audience could accept female clowns in Yala "because we only perform for our relatives, close friends and community in the village.” There was only one other woman named Jamilah who was a well-known Peran Muda before her. In 2019, only Che Som and another actress by the name of Minah were able to play the Peran Muda clown part in south Thailand. Che Som's final show was the one that we described earlier at the Ke-Meng Fol Museum Chalermraja Cultural Centre in July 2019 at Raman. She passed away in March 2020.

Alee Chehama who played the Peran Tua character alongside Che Som was another Makyong performer who left this world in April 2020 (Figure 5). Born on 10 February 1952, Alee Chehama hailed from Chaerong, Narathiwat. His family was also involved in theatre; his father played the rebab in Mak Yong while his uncle was the main puppeteer of a wayang kulit troupe. He started learning the serunai and rebab and took part in Main Puteri ritual healing ceremonies as the Tok Puteri (rebab player who communicated with the supernatural) when he was 27 years old. With his background as a Tok Puteri, Alee Chehama began to learn the Peran Tua role in Makyong. "To be a good Peran Tua, one must have a good voice, know how to sing and dance and understand the philosophy of religion and about life," he stressed. "We must respect and remember our teachers," he asserted (personal communication, 29 July 2019, Yala). 


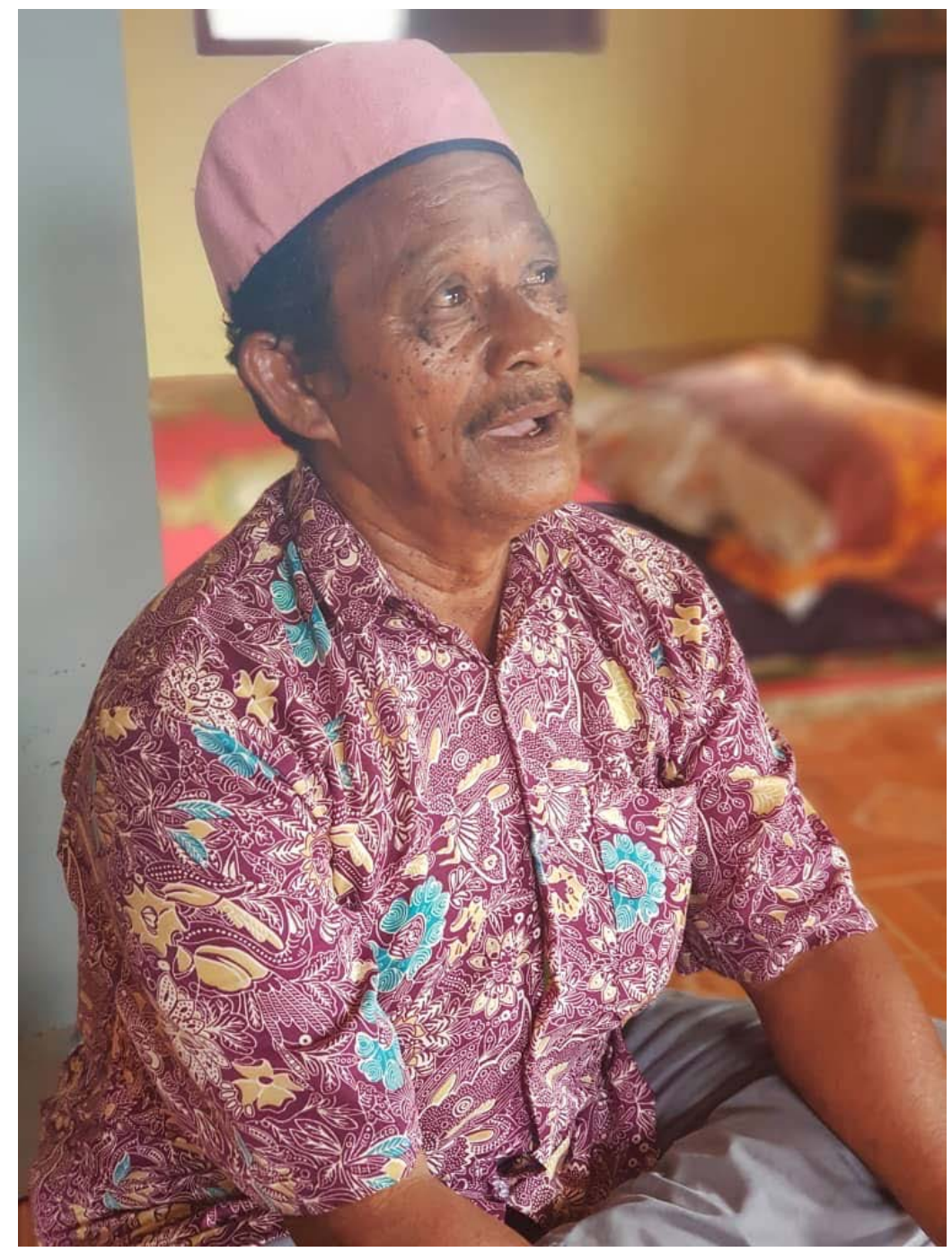

Fig. 5 Alee Chehama, the Peran Tua. Source: A. S. Hardy Shafii.

Another remaining prima donna in Yala is Mek Munoh (also known as Seetee Meenoh Samea, Figure 6). Born on 1 January, 1944, Mek Munoh is famous for her role as the Pak Yong or Raja. The 77 year old mother of seven, still does some rubber tapping to earn her pocket money. Like most performers in Yala, Mek Munoh came from a family of Makyong actors and actresses. Her father, Jusoh, was a bomoh (shaman) and her sister Siti Ratna played the Mak Yong or Queen character. Mek Munoh married at the tender age of 13 and graduated as a Pak Yong when she was 15 years old.

What was her training like? "I learnt to dance first as singing was rather difficult," she said. I had to internalize the singing and remember how to "sing from the heart especially the songs like lagu Fikir and Kijang Mas (Golden Deer). The lagu Gerak Bangun segment took me three nights to learn. I watched the older Pak Yong perform and followed the movements," she emphasized (personal communication, 28-29 July, 2019, Yala). Mek Munoh quickly added that the Pak Yong role was not only performed by actresses but also by actors and cited her father, Jusoh, Pak Su Mat Hindustan, Pak Su Mat Kadir and Che Muda as some examples. 
Mek Munoh underscored that "if women want to play the Pak Yong role, they have to learn how to wear the Pak Yong costume: black shirt and pants, red kain songket (type of cloth interwoven with metallic threads) and tanjak (male headgear). The Pak Yong must wear a watch as a symbol of status!" "The Pak Yong must also be able to sing, dance and act," she continued.

Mek Munoh recalled that she had to go through the upacara sembah guru, a ceremony to pay respects to the spiritual teacher before she graduated as a Pak Yong performer. "To enter the stage (masuk panggung), we must first remember our teacher. He will protect us from any harm during performances. Following the instructions of the shaman, we prepared offerings that included yellow rice (nasi kunyit), yellow glutinous rice (pulut), eggs (telur), ayam panggang (roasted chicken), raw thread (benang mentah), betel nut (pinang sepiak) and duit keneri 12 sen (12 cent coins)," she underlined.

Mek Munoh laments that there are few Makyong performances now; in contrast she was even invited to perform in Terengganu, Kota Bharu, Bangkok and Riau in 1995-96. Further, very few young people want to learn Makyong. Nevertheless, she is happy her 16-year old grandaughter, Yasmin Ibrahim, seems interested. "She follows me whenever I perform; she is a member of the Jung Dondang (chorus) and dances in the Gerak Bangun and Fikir sections,” Mek Munoh proudly declares.

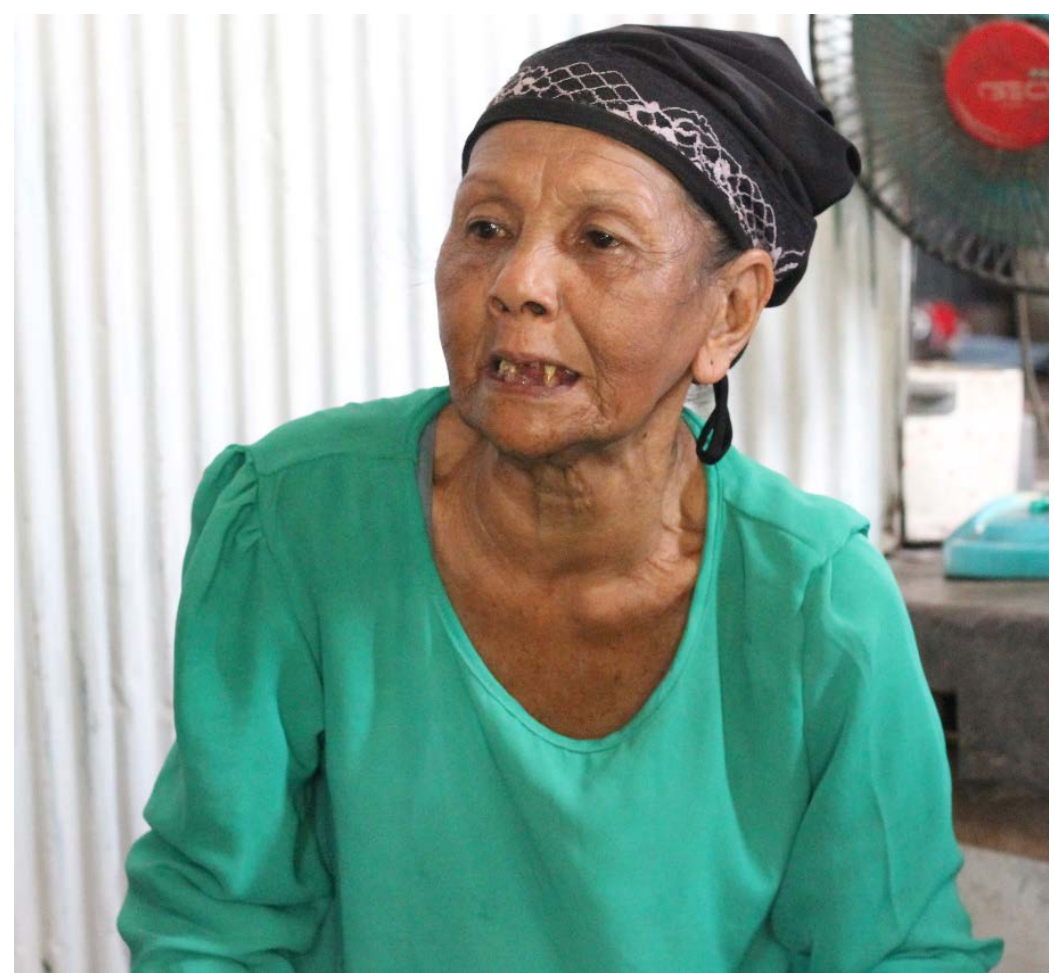

Fig. 6 Mek Munoh, the female Pak Yong. Source: A. S. Hardy Shafii.

Musicians also play vital roles in Makyong; without them there will be no show. Che Dae or Jehdey Sa-ni (born in 1941, Figure 7) is probably the only surviving rebab player left in south Thailand. In his heyday, he had performed in Kelantan and Besut. He works as a rubber tapper when there are no Makyong performances. Che Dae learnt and played the gendang in Makyong when he was 10 years old. In the early days, he performed with three Makyong groups named Che Ning, Penawar and Kak Wei. Like Mek Munoh, he also bemoaned "there are no young people who want to learn the rebab” (personal communication, 30 July, 2019, Yala). 


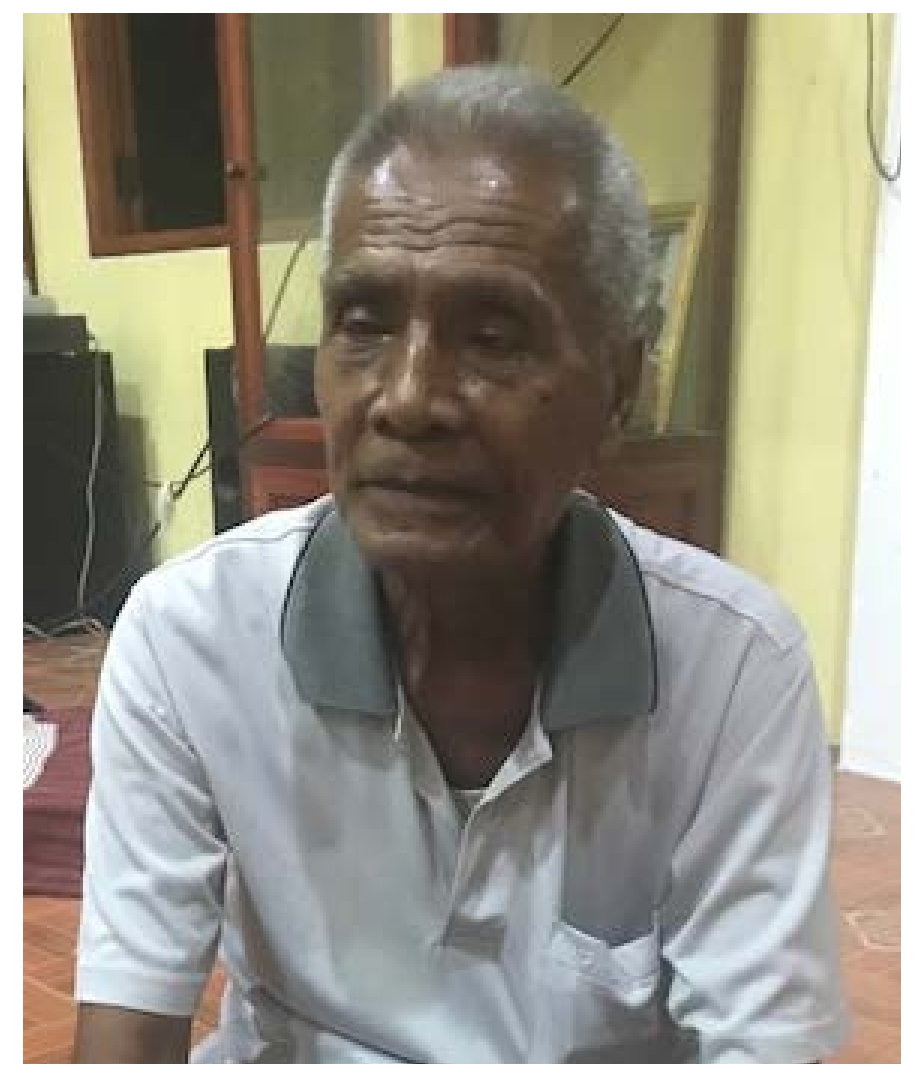

Fig. 7 Che Dae, the rebab player. Source: A. S. Hardy Shafii.

The memories of the veteran performers give us a sense of what it was like to be a Malay-Muslim Makyong performer in Yala, Narathiwat and Patani in the last century. The passing of Che Som and Alee Chehama is emblematic of the end of an era of Makyong theatre with its female clowns and prima donnas in South Thailand.

\section{Acknowledgements}

We would like to thank Universiti Sains Malaysia for the Research University Grant (1001/PSENI/8016017) that enabled us to conduct research in south Thailand and Saman Dosormi who assembled the performers and arranged for the performance at the Ke-Meng Folk Museum Chalermraja Cultural Centre Museum, Raman, Yala. We are grateful to all the Makyong performers of Yala who granted interviews and performances and to our graduate assistant, Rosnan Abdul Rahman, for his help during fieldwork.

\section{References}

Amirell, S (2011) The Blessings and Perils of Female Rule: New Perspectives on the Reigning Queens of Patani, c. 1584-1718. Journal of Southeast Asian Studies, 42(2): 303-323.

Hardwick, P (2014) The Body Becoming: Transformative Performance in Malaysian Mak Yong. Music and Medicine, 6(1): 40-48.

Hardy Shafii, AS and Johan Othman, A (2020) Structural Dialectics of Makyong in Yala. New Sunday Times, July 19: 23. 
Hardy Shafii, AS (2017) The Historical Journey of Makyung. In: AS Hardy Shafii (ed.) Perspectives on Malaysia's Traditional Theatre. Kuala Lumpur: Dewan Bahasa dan Pustaka, 1-19.

Teeuw, A and Wyatt, DK (1970) Hikayat Patani: The Story of Patani, Vol. 1-2. The Hague: Martinus Nijhoff.

Yousof, G-S (1982) Makyong: The Ancient Malay Dance-Theatre. In: G-S Yousof (ed.) Asian Studies. Manila: University of the Philippines, Asian Centre, 108-121.

\section{Interviews}

Che Som or Jehsong Samae (born on 1 January 1949), female Peran Muda, Ke-Meng Folk Museum Chalermraja Cultural Centre, 56 M001 Arzong sub-wilayah Raman, Yala, Thailand, 28 Julai 2019. She passed away in March 2020.

Saman Dosormi (born on 19 July 1973), head of Makyong Seri Bulan Tarian, Yala, Thailand, KeMeng Folk Museum Chalermraja Cultural Centre, 56 M001 Arzong sub-wilayah Raman, Yala, Thailand, 28 July 2019.

Mek Munoh or Seeteemeenoh Samea (born on 1 January 1944), primadona Pak Yong, Amphoe Mueang Yala-Tha Sap and Raman, Yala, 28-30 July, 2019.

Mak Timoh or Miss Tuanmoh Dayordalee (born on 4 February 1948). Mak Yong actress, Yala, 30 July 2019.

Alee Chehama (born on 10 February 1952), male Peran Tua, Yala, 29 July, 2019. He passed away in April 2020.

Che Dae or Jehdey Sa-ni (born in 1941), Yala, 30 July 2019. 